\title{
Influence of adhesive system on quartz fiber post dislocation resistance in endodontically treated teeth
}

\author{
Luis Francisco Maglione García', Vicente Castelo Branco Leitune², Stéfani Becker Rodrigues², \\ Susana Maria Werner Samuel2, Fabrício Mezzomo Collares²
}

1Universidad de La República - UDELAR, Facultad de Odontología, Area of Operative Dentistry, Montevideo, Uruguay
${ }^{2}$ Universidade Federal do Rio Grande do Sul - UFRGS, Department of Conservative Dentistry, Porto Alegre, RS, Brazil

Chiveridade Federaldo Rio Grande do Sul-UFRGS, Depatment of Conservative Dentisty, Poto Alegre, RS, Brazil

Abstract

Received for publication: April 25, 2016 Accepted: August 03, 2016

Correspondence to: Fabrício Mezzomo Collares Rua Ramiro Barcelos 2492 Laboratório de Materiais Dentários Universidade Federal do Rio Grande do Sul - UFRGS Porto Alegre, Brazil. 90035-003 Phone/fax: +55513308 5198 . E-mail: fabricio.collares@ufrgs.br
Aim: To evaluate the dislocation resistance of the quartz fiber post/cement/dentin interface after different adhesion strategies. Methods: Forty bovine lower central incisors were selected and prepared with K-files using the step-back technique, and irrigated with $3 \mathrm{~mL}$ of distilled water preceding the use of each instrument. Prepared teeth were stored at $37^{\circ} \mathrm{C}$ and $100 \%$ humidity for 7 days. The roots were prepared and randomized into 4 groups. The quartz fiber post was cemented with an adhesion strategy according to the following groups: $G_{B i s C e m}-B I S C E M ; G_{\text {OneStep } \pm C \& B}-$ One Step $\pm \mathrm{C} \& \mathrm{~B} ; \mathrm{G}_{\text {AllBond } \pm C \& B}-$ AllBond3 $\pm \mathrm{C} \& \mathrm{~B} ; \mathrm{G}_{\text {AllBondSE } \pm C \& B}-$ AllBondSE $\pm C \& B$ with a quartz fiber post. Cross-sectional root slices of $0.7 \mathrm{~mm}$ were produced and stored for $24 \mathrm{~h}$ at $37^{\circ} \mathrm{C}$ before being submitted to push-out bond strength. Results: The mean and standard deviation values of dislocation resistance were $\mathrm{G}_{\text {BisCem }}: 1.12( \pm 0.23) \mathrm{MPa}, \mathrm{G}_{\text {OneStep } \pm C \& B}: 0.81( \pm 0.31) \mathrm{MPa}, \mathrm{G}_{\text {AllBond } \pm C \& B}$ : $0.98( \pm 0.14) \mathrm{MPa}$, and $\mathrm{G}_{\text {AllBondSE } \pm C \& B}: 1.57( \pm 0.04) \mathrm{MPa}$. $\mathrm{G}_{\text {AllBondSE } \pm C \& B}$ showed significantly higher values of dislocation resistance than the other groups. Conclusions: Based on this study design, it may be concluded that adhesion strategies showed different results of quartz post dislocation resistance. Simplified adhesive system with sodium benzene sulphinate incorporation provided superior dislocation resistance.

Keywords: Tooth, Endodontically-Treated. Post and Core Technique. Resin Cements. DentinBonding Agents.

\section{Introduction}

The objectives of the restorative treatment of endodontically treated teeth with large crown destruction are giving the teeth more resistance to masticatory forces, reestablishing function, and esthetics ${ }^{1}$. Thus, sometimes the use of intraradicular post and cores is necessary ${ }^{2,3}$. Ideally, the intraradicular post and cores should not move into the root canal and forces are distributed in the teeth homogeneously, decreasing the risk of tooth fractures ${ }^{4,5}$.

Cast metal posts have been used for a long time in clinical practice and have presented high survival rates ${ }^{6}$. Metal posts have high elastic modulus, which increases fracture and catastrophic root failure. Therefore, glass fiber posts have been introduced as an alternative. Due to their low elastic modulus compared with cast metal posts, glass fiber posts have decreased the number of catastrophic failures ${ }^{7}$. In addition, they are more aesthetic and result in less clinical time $e^{3,8,9}$. 
Carbon-fiber posts were introduced in the 1990s, and after that other types were produced such as glass fiber posts and zirconia and quartz posts. Fiber posts are cemented with a polymer luting cement to dentin due to chemistry affinity for its own epoxy resin matrix with the resin cement and quartz posts presenting a $98 \%$ survival rate after 9 years ${ }^{9}$. However, difficulty in adhesive cementation is observed and debonding is the main type of failure ${ }^{10-15}$. It is important to know which adhesive strategy should be used to decide the best choice for fiber post cementation ${ }^{16}$. Thus, the objective of this study was to evaluate the dislocation resistance of the quartz fiber post/ cement/dentin interface after different adhesion strategies. The null hypothesis was that the different adhesion strategies would not affect the dislocation resistance.

\section{Material and methods}

\section{Teeth preparation}

Forty bovine incisors were selected for this study. To be included, the following criteria had to be met: straight roots and a root length of at least $15 \mathrm{~mm}$. External debris were removed with a periodontal curette and scalpel blade. The teeth were sectioned transversely $15 \mathrm{~mm}$ from the apex using a slow-speed diamond disc under water coolant, the pulp tissue was removed, and chemomechanical preparation was performed according described previously ${ }^{17,18}$. The root canals were prepared with K-files using the step-back technique and irrigated with $3 \mathrm{~mL}$ of distilled water preceding the use of each instrument. After that, they were stored at $37^{\circ} \mathrm{C}$ and $100 \%$ humidity for 7 days. Subsequently, the roots were prepared (Figure 1) with a specific Bisco burr (BISCO Int., Schaumburg, Illinois, USA), and randomized into 4 groups. Quartz fiber post was cemented according to the adhesive system and cements (Table 1). Fiber posts had $12 \mathrm{~mm}$ of length, $1.8 \mathrm{~mm}$ of cervical diameter and $1.0 \mathrm{~mm}$ of apical diameter.

Table 1 - Groups, materials and methods used in the study.

\begin{tabular}{|c|c|c|}
\hline Group & Material & Method \\
\hline $\mathrm{G}_{\text {BisCem }}$ & BisCem Cement (BISCO) & $\begin{array}{l}\text { Mixed for } 15 \mathrm{~s} \text {, applied to the post and } \\
\text { root canal; photoactivated for } 30 \mathrm{~s} \text {. }\end{array}$ \\
\hline \multirow[t]{3}{*}{$\mathrm{G}_{\text {OneStep } \pm C \& B}$} & $\begin{array}{l}\text { Phosphoric acid } 35 \% \\
\text { (Coltene/Whaledent, } \\
\text { Cuyahoga Falls, Ohio, USA) }\end{array}$ & $\begin{array}{l}\text { Applied for } 15 \mathrm{~s} \text {; rinsed with distilled } \\
\text { water; dried with absorbent paper } \\
\text { cones. }\end{array}$ \\
\hline & One Step (BISCO) & $\begin{array}{l}\text { Applied for } 20 \mathrm{~s} \text {; dried with absorbent } \\
\text { paper cones; photoactivated for } 20 \mathrm{~s} \text {. }\end{array}$ \\
\hline & C\&B Cement (BISCO) & $\begin{array}{l}\text { Mixed for } 15 \mathrm{~s} \text {; applied in the post and } \\
\text { root canal. }\end{array}$ \\
\hline \multirow[t]{3}{*}{$\mathrm{G}_{\text {AllBond } \pm C \& B}$} & $\begin{array}{l}\text { Phosphoric acid 35\% } \\
\text { (Coltene/Whaledent) }\end{array}$ & $\begin{array}{l}\text { Applied for } 15 \mathrm{~s} \text {; rinsed with distilled } \\
\text { water; dried with absorbent paper } \\
\text { cones. }\end{array}$ \\
\hline & All Bond 3 A \& B (BISCO) & $\begin{array}{l}\text { Mixed primer A and B for } 5 \text { s; applied } \\
\text { for } 20 \text { s; dried with absorbent paper } \\
\text { cones; applied adhesive resin and } \\
\text { photoactivated for } 20 \text { s. }\end{array}$ \\
\hline & C\&B Cement (BISCO) & $\begin{array}{l}\text { Mixed for } 15 \mathrm{~s} \text {; applied in the post and } \\
\text { root canal. }\end{array}$ \\
\hline \multirow[t]{3}{*}{$\mathrm{G}_{\text {AllBondSE } \pm C \& B}$} & $\begin{array}{l}\text { Phosphoric acid 35\% } \\
\text { (Coltene/ Whaledent) }\end{array}$ & $\begin{array}{l}\text { Applied for } 15 \mathrm{~s} \text {; rinsed with distilled } \\
\text { water; dried with absorbent paper } \\
\text { cones. }\end{array}$ \\
\hline & All Bond SE I and II (BISCO) & $\begin{array}{l}\text { Mixed part I and part II for } 5 \mathrm{~s} \text {; applied } \\
\text { for } 20 \text { s dried with absorbent paper } \\
\text { cones; photoactivated for } 20 \mathrm{~s} \text {; }\end{array}$ \\
\hline & C\&B Cement (BISCO) & $\begin{array}{l}\text { Mixed for } 15 \mathrm{~s} \text {; applied in the post and } \\
\text { root canal. }\end{array}$ \\
\hline
\end{tabular}

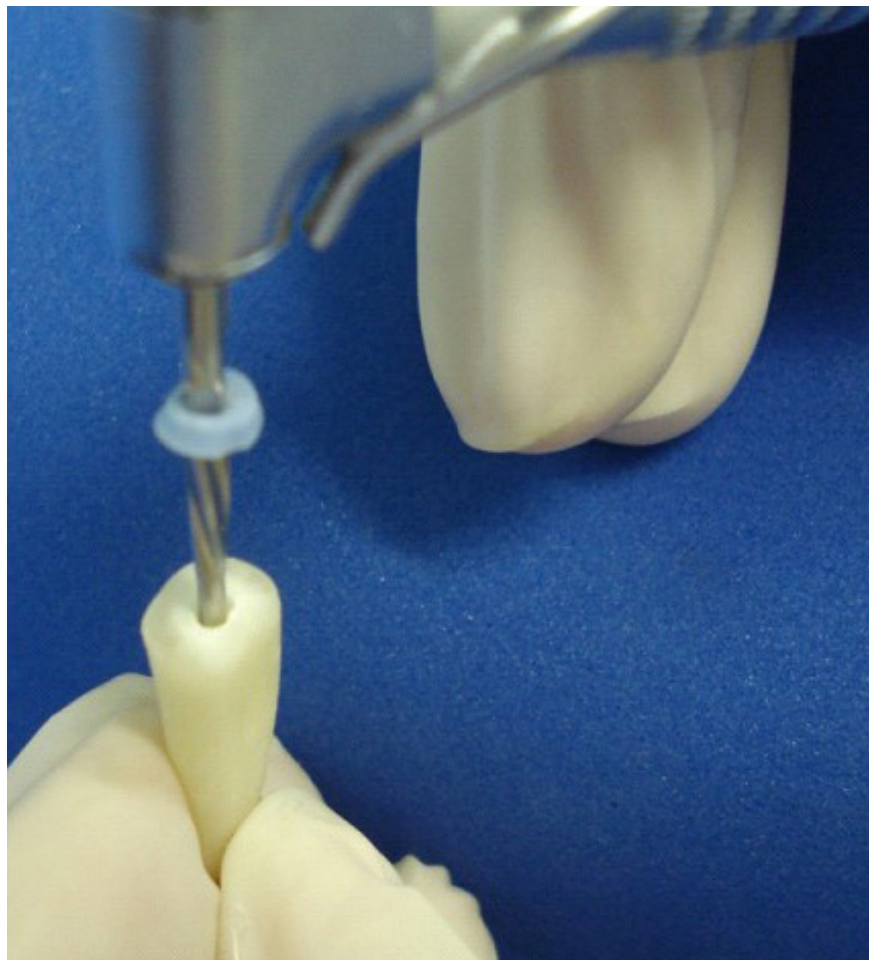

Fig.1. Roots prepared with specific bur.

\section{Push-out test}

After cementation of the quartz post, the teeth were sectioned transversely into 7 slices that were approximately $0.7 \mathrm{~mm}$ thick using a low-speed disc (Isomet, Buehler Ltd, Lake Bluff, IL, USA) with constant water cooling. The internal diameter of the canal of each slice was measured with a digital caliper (Digimess, 100.174BL, Digimess Instrumentos de Precisão Ltda, São Paulo, SP, Brazil) and the contact area between the filling and dentin of each slice was calculated. Each slice was placed with the apical side up on a mechanical testing machine (DL-2000, EMIC Equipamentos e Sistemas de Ensaio Ltda, São José dos Pinhais, PR, Brazil). A force was applied to the shutter toward the apical neck using a $500 \mathrm{~N}$ load cell and a crosshead speed of $1 \mathrm{~mm} / \mathrm{min}$ with a $0.8-\mathrm{mm}$ diameter cylindrical device. The dislocation resistance $(\mathrm{MPa})$ was obtained by dividing the force $(\mathrm{N})$ required to displace the filling material by the adhesive area $\left(\mathrm{mm}^{2}\right)$. The adhesive area was calculated using (1 and 2):

$$
\begin{aligned}
& \mathrm{g}=\left(\mathrm{h}^{2} \pm(\mathrm{R} 2-\mathrm{R} 1)^{2}\right)^{1 / 2} \\
& \mathrm{~A}=\pi \cdot \mathrm{g} \cdot(\mathrm{R} 1 \pm \mathrm{R} 2)
\end{aligned}
$$

where, $\mathrm{g}$ is the root taper, $\mathrm{R} 1$ represents the apical radius, $\mathrm{R} 2$ represents the coronal radius, $\mathrm{h}$ is the thickness of the slice, and $\mathrm{A}$ is the adhesive area.

Apical and coronal radii were obtained from photographs and measured with Image Tool software 10 times from different sides to obtain the radii means (Figure 2).

\section{Statistical Analysis}

Data normality was checked by the Kolmogorov-Smirnov test. Data were analyzed by ANOVA and the Tukey post-hoc test. A significance level of $5 \%$ was used for analysis. 


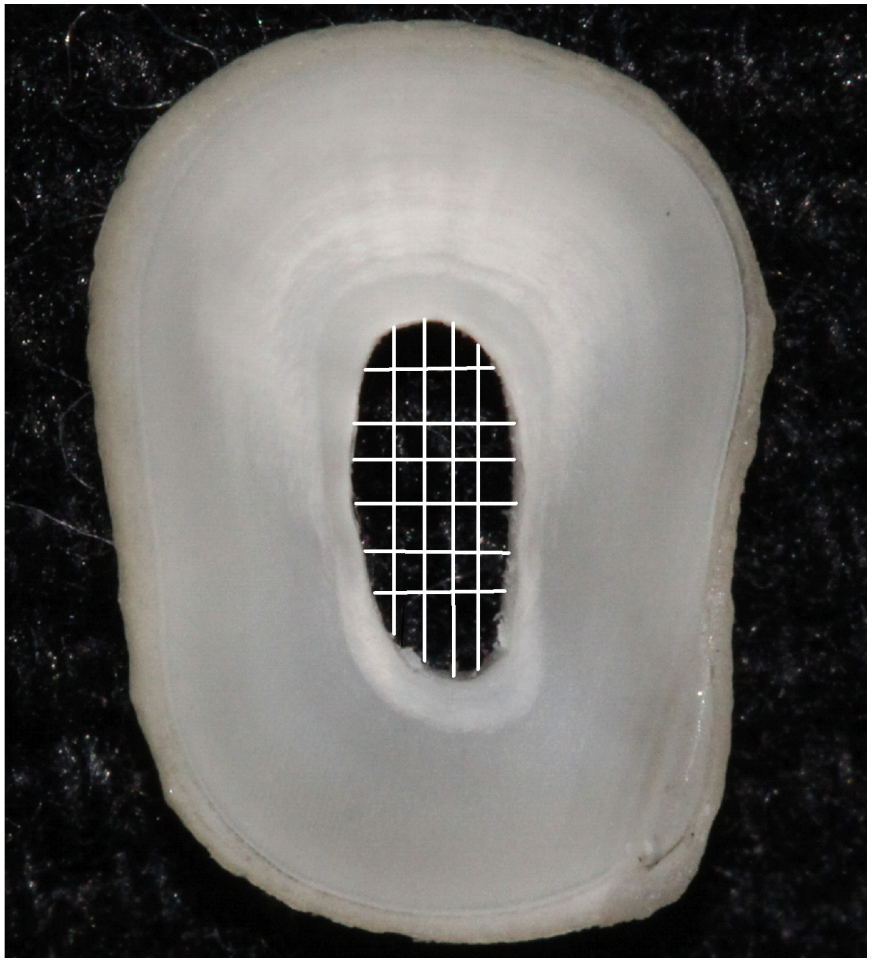

Fig.2. Photograph of canal slice and measurement of internal diameter with software in 10 different regions.

\section{Results}

The results of the dislocation resistance are shown in Table 2 and Figure 3. The $\mathrm{G}_{\text {AllBondSE } \pm \text { C\&B }}$ group presented the highest dislocation resistance value $(1.57 \pm 0.04 \mathrm{MPa})$, with a significant difference from the other groups, $\mathrm{p}<0.05$. $\mathrm{G}_{\text {BisCem }}(1.12 \pm 0.23 \mathrm{MPa}), \mathrm{G}_{\text {OneStep } \pm \text { C\&B }}(0.81 \pm 0.31 \mathrm{MPa})$, and $\mathrm{G}_{\text {AllBondSE } \pm \text { C\&B }}(0.98 \pm 0.14 \mathrm{MPa})$ did not show statistically significant differences between each other, $\mathrm{p}>0.05$.

\section{Discussion}

In this study, the dislocation resistance of root dentin/cement/ post was evaluated after different adhesive strategies. The materials in this study showed easy clinical use, furthermore, the decreased catastrophic failure could have occurred as result of correct dissipation of forces in the middle third of teeth. The use of fiber post with resin cement leads to a block formation with dental tissue since the elastic modulus is similar to dentin $(18 \mathrm{GPa})$, once the values for fiber post is between 16-40 GPa and resin cement between 6.8-10.8 $\mathrm{GPa}^{19}$. However, the adhesive system strategies used in this study showed different results for dislocation resistance, and the highest values were found in the $\mathrm{G}_{\text {AllBondSE } \pm \text { C\&B }}$ group.

Difficulty in hybrid layer formation results in ineffective adhesion and a decrease in dislocation resistance due to: high factor cavity configuration, high polymerization shrinkage, and difficulty in the homogeneous acid condition of the root walls ${ }^{8}$. In the $\mathrm{G}_{\text {BisCem }}$ group, self-adhesive cement was used. This cement compounds the acid monomers, which demineralize the dentin substrate while infiltrating the monomers to form a hybrid layer. It is likely that the lower dislocation resistance occurred due to the fact that there was no formation of a homogeneous hybrid layer ${ }^{14}$.

Table 2 - Results of mean and standard deviation, in MPa, of dislocation resistance (DR) with different adhesive cements.

\begin{tabular}{lc}
\hline Groups & $D R(M P a)$ \\
$G_{\text {BisCem }}$ & $1.12( \pm 0.23) B^{*}$ \\
$G_{\text {OneStep } \pm \& \& B}$ & $0.81( \pm 0.31) B$ \\
$G_{\text {AllBond } \pm \text { C\&B }}$ & $0.98( \pm 0.14) B$ \\
$G_{\text {AllBondSE } \pm \text { C\&B }}$ & $1.57( \pm 0.04) A$ \\
\hline
\end{tabular}

*Different capital letters indicates statistically significant difference within the column $(p<0.05)$

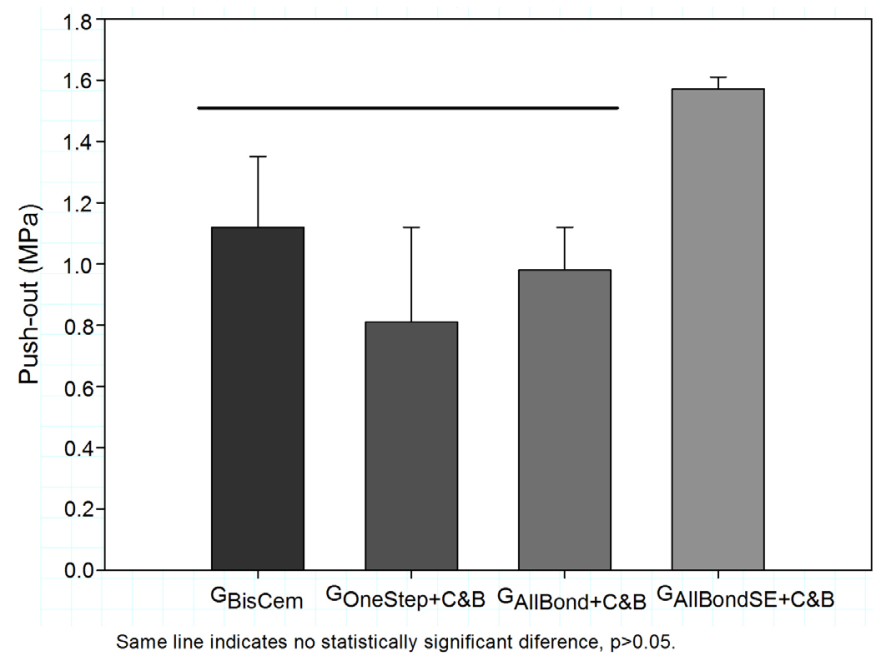

Fig.3. Push-out (MPa) values of groups tested ( $G_{\text {BisCem }}, G_{\text {OnesteptC\&B}}, G_{\text {AllBond } \pm C \& B}$ and $\left.\mathrm{G}_{\text {AllBondSE } \pm C \& B}\right)$.

The simplified adhesive systems (primer with adhesive) showed statistically significant lower dislocation resistances between groups $\left(\mathrm{G}_{\text {OneStep } \pm \text { C\&B }}\right.$ and $\left.\mathrm{G}_{\text {AllBondSE } \pm \text { C\&B }}\right), p<0.05 \%$. One Step adhesive is a universal self-adhesive of one plot that presents hydrophilic monomers (hydroxyethyl methacrylate), acid monomers, and acetone as solvent. Hydroxyethyl methacrylate presents low hydrolytic stability when in the same environment with acid monomers and degrades in little time. Furthermore, acetone solvents have high volatility, which makes the operatory technique difficult and justifies the low value of dislocation resistance ${ }^{20}$. However, in this study, a significant difference between the $\mathrm{G}_{\text {OneStep } \pm \text { C\&B }}$ (universal adhesive), 0.81 ( \pm 0.31 ), and $\mathrm{G}_{\text {AllBond } \pm \text { C\&B }}$ (etch-and-rinse adhesive), 0.98 ( \pm 0.14 ), groups was not observed, $\mathrm{p}>0.05 \%$. Conventional adhesive systems, with 3 steps etch-and-rinse, present difficulties related to incomplete acid filling of the root and incorrect evaporation of the primer solvent, compromising the adhesion process, mainly in the medium and apical thirds ${ }^{13,14,21,22}$.

The highest values of dislocation resistance were found in the $\mathrm{G}_{\text {AllBondSE } \pm \text { C\&B }}$ group. It is likely that the compound present in part I of the adhesive, sodium benzene sulphinate, acts as a co- 
initiator in the acid-base reaction between benzoyl peroxide and tertiary amine of the chemically cured resin cements, increasing the results of dislocation resistance ${ }^{23-25}$. The sodium benzene sulphinate allows the acidity of the adhesive system to demineralize the dentin substrate without interfering in the resin cement degree of conversion. Thus, it is possible that the incorporation of the coinitiator avoids the chemical incompatibility between simplified adhesives and chemically cured resin cements.

Based on this study design, it is licit to conclude that the adhesion strategies showed different results of quartz post dislocation resistance. The simplified adhesive system with sodium benzene sulphinate incorporation presented superior dislocation resistance.

\section{Acknowledgements}

This study received no specific grant from any funding agency in the public, commercial or not-for-profit sector. No conflits of interest are present. The authors gratefully acknowledge CAPES for the scholarship (SBR).

\section{References}

1. Sequeira-Byron P, Fedorowicz Z, Carter B, Nasser M, Alrowaili EF. Single crowns versus conventional fillings for the restoration of root-filed teeth. Cochrane Database Syst Rev. 2015 Sep 25;(9):CD009109. doi: 10.1002/14651858.CD009109.pub3.

2. Perdigao J, Gomes G, Augusto V. The effect of dowel space on the bond strengths of fiber posts. J Prosthodont. 2007 May-Jun;16(3):154-6.

3. Lamichhane $A, X u C$, Zhang FQ. Dental fiber-post resin base material: a review. JAdv Prosthodont. 2014 Feb;6(1):60-5. doi: 10.4047/jap.2014.6.1.60.

4. Bosso K, Gonini Júnior A, Guiraldo RD, Berger SB, Lopes MB. Stress generated by customized glass fiber posts and other types by photoelastic analysis. Braz Dent J. 2015 May-Jun;26(3):222-7. doi: 10.1590/01036440201300256.

5. Sterzenbach G, Franke A, Naumann M. Rigid versus flexible dentine-like endodontic posts--clinical testing of a biomechanical concept: seven-year results of a randomized controlled clinical pilot trial on endodontically treated abutment teeth with severe hard tissue loss. J Endod. 2012 Dec;38(12):155763. doi: 10.1016/j.joen.2012.08.015.

6. Gomez-Polo M, Llido B, Rivero A, Del Rio J, Celemin A. A 10- year retrospective study of the survival rate of teeth restored with metal prefabricated posts versus cast metal posts and cores. $2010 \mathrm{Nov} ; 38(11): 916$ 20. doi: 10.1016/j.jdent.2010.08.006.

7. Jindal S, Jindal R, Mahajan S, Dua R, Jain N, Sharma S. In vitro evaluation of the effect of post system and length on the fracture resistance of endodontically treated human anterior teeth. Clin Oral Investig. 2012 Dec;16(6):1627-33. doi: 10.1007/s00784-012-0673-9.

8. Soares CJ, ValdiviaAD, da Silva GR, Santana FR, Menezes MS. Longitudinal clinical evaluation of post systems: a literature review. Braz Dent J. 2012;23(2):135-40.

9. Gbadebo OS, Ajayi DM, Oyekunle OO, Shaba PO. Randomized clinical study comparing metallic and glass fiber post in restoration of endodontically treated teeth. Indian J Dent Res. 2014 Jan-Feb;25(1):58-63. doi: 10.4103/0970-9290.131126.

10. Parisi C, Valandro LF, Ciocca L, Gatto MR, Baldissara P. Clinical outcomes and success rates of quartz fiber post restorations: a retrospective study. J Prosthet Dent. 2015 Sep;114(3):367-72. doi: 10.1016/j. prosdent.2015.03.011.

11. Amarnath GS, Swetha MU, Muddugangadhar BC, Sonika R, Garg A, Rao TR Effect of Post Material and Length on Fracture Resistance of Endodontically Treated Premolars: An In-Vitro Study. J Int Oral Health. 2015 Jul;7(7):22-8.

12. Gbadebo OS, Ajayi DM, Oyekunle OO, Shaba PO. Randomized clinical study comparing metallic and glass fiber post in restoration of endodontically treated teeth. Indian J Dent Res. 2014 Jan-Feb;25(1):58-63. doi: 10.4103/0970-9290.131126.

13. Schwartz RS. Adhesive dentistry and endodontics. Part 2: bonding in the root canal system-the promise and the problems: a review. J Endod. 2006 Dec;32(12):1125-34

14. Skupien JA, Sarkis-Onofre R, Cenci MS, Moraes RR, Pereira-Cenci T. A systematic review of factors associated with the retention of glass fiber posts. Braz Oral Res. 2015;29. pii: S1806-83242015000100401. doi: 10.1590/1807-3107BOR-2015.vol29.0074.

15. Akin GE, Akin H, Sipahi C, Piskin B, Kirmali O. Evaluation of surface roughness and bond strength of quartz fiber posts after various pre-treatments. Acta Odontol Scand. 2014 Nov;72(8):1010-6. doi: 10.3109/00016357.2014.939710.

16. Collares FM, Portella FF, Rodrigues SB, Celeste RK, Leitune VC, Samue $\mathrm{SM}$. The influence of methodological variables on the push-out resistance to dislodgment of root filling material: a meta-regression analysis. Int Endod J. 2015 Sep 1. doi: 10.1111/iej.12539.

17. Collares FM, Klein M, Santos PD, Portella FF, Ogliari F, Leitune VC, et al. Influence of radiopaque fillers on physicochemical properties of a model epoxy resin-based root canal sealer. J Appl Oral Sci. 2013 NovDec;21(6):533-9. doi: 10.1590/1679-775720130334.

18. Rocha AW, de Andrade CD, Leitune VC, Collares FM, Samuel SM, Grecca $\mathrm{FS}$, et al. Influence of endodontic irrigants on resin sealer bond strength to radicular dentin. Bull Tokyo Dent Coll. 2012;53(1):1-7.

19. Boschian Pest L, Cavalli G, Bertani P, Gagliani M. Adhesive post-endodontic restorations with fiber posts: push-out tests and SEM observations. Dent Mater. 2002 Dec;18(8):596-602.

20. De Munck J, Van Landuyt K, Peumans M, Poitevin A, Lambrechts P, Braem $\mathrm{M}$, et al. A critical review of the durability on adhesion to tooth tissue: methods and results. J Dent Res. 2005 Feb;84(2):118-32.

21. Goracci $C$, Ferrari M. Current perspectives on post systems: a literature review. Aust Dent J. 2011 Jun;56 Suppl 1:77-83. doi: 10.1111/j.18347819.2010.01298.x.

22. Mallmann A, Jacques LB, Valandro LF, MuenchA. Microtensile bond strength of photoactivated and autopolymerized adhesive systems to root dentin using translucent and opaque fiber-reinforced composite posts. J Prosthet Dent. 2007 Mar;97(3):165-72.

23. Arrais $C A$, Giannini M, Rueggeberg FA. Effect of sodium sulfinate salts on the polymerization characteristics of dual-cured resin cement systems exposed to attenuated light-activation. J Dent. 2009 Mar;37(3):219-27. doi: 10.1016/j.jdent.2008.11.016.

24. Tay FR, Suh BI, Pashley DH, Prati C, Chuang SF, Li F. Factors contributing to the incompatibility between simplified-step adhesives and self-cured or dual-cured composites. Part II. Single-bottle, total-etch adhesive. J Adhes Dent. 2003 Summer;5(2):91-105.

25. Suh $\mathrm{BI}$, Feng L, Pashley DH, Tay FR. Factors contributing to the incompatibility between simplified-step adhesives and chemically-cured or dual-cured composites. Part III. Effect of acidic resin monomers. J Adhes Dent. 2003 Winter;5(4):267-82. 